Bryn Mawr College

Scholarship, Research, and Creative Work at Bryn Mawr College

2010

\title{
The Garden of Earthly Delights: Mahaut of Artois and the Automata at Hesdin
}

Elly Truitt

Bryn Mawr College, etruitt@brynmawr.edu

Let us know how access to this document benefits you.

Follow this and additional works at: http://repository.brynmawr.edu/history_pubs

Part of the History Commons

\section{Custom Citation}

Truitt, Elly R. "The Garden of Earthly Delights: Mahaut of Artois and the Automata at Hesdin." Medieval Feminist Forum: A Journal of Gender and Sexuality 46, no. 1 (2010) : 74-79.

This paper is posted at Scholarship, Research, and Creative Work at Bryn Mawr College. http://repository.brynmawr.edu/history_pubs/27

For more information, please contact repository@brynmawr.edu. 


\section{The Garden of Earthly Delights: Mahaut of Artois and the Automata at Hesdin}

Elly R. Truitt

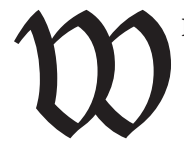

Hen Monica Green first asked me if I would like to take part in this session to honor Joan and her contribution to the field of medieval intellectual history (as well as the history of science), I immediately said, "yes." After meeting with Joan here at Kalamazoo in 2006, she agreed to be one of my dissertation readers, despite the fact that we had only met once before and were (and are) located on opposite coasts. For the next eighteen months she was a tireless and exacting reader of my work. She asked probing questions that forced me to reconsider my assumptions, my evidence, and my conclusions, and she offered critical suggestions at several different stages. In the time since I have completed my dissertation on medieval automata, she has also given me helpful advice on the job market, as well as being a fantastic mentor for newer projects. It is an honor for me to be a part of this celebration of her contributions to our fields today.

When I considered how I might best participate in this session, I thought that I might take this opportunity to look more closely at a figure who appeared in my dissertation, but whose impact on my subject matter I had left largely unexamined in favor of other directions. Mahaut, Countess of Artois and Burgundy, was the seigneur of Hesdin (among other places) from 1302 to I329, and while she was countess of Artois, she spent significant sums on the maintenance, renovation, and installation of automata in the park at Hesdin. Looking more carefully at the archival sources that detail the work done at Hesdin during this period, as well as looking more in depth into her biography, I wondered if it would be possible to make a case for her role as a patron of innovations in art and mechanical technology as well as investigating a link between the automata at Hesdin and the proliferation of mechanized table fountains at the French royal court. 
The first automata-actually or apparently self-moving manufactured objects, most often in the shape of animals and people-built in Europe were located in the park at Hesdin, a chateau in the county of Artois, near the current border between France and the Netherlands. These automata were built at the behest of Robert II, Count of Artois, in the last decade of the thirteenth century. After he died in $\mathrm{I} 3 \mathrm{O} 2$, his daughter, Mahaut (also called Matilda), inherited his title and lands and remained Countess of Artois, as well as Countess of Burgundy (her title by marriage), until her death in 1329.

Hesdin was famous for its automata until the estate and the automata fell into disrepair in the late fifteenth century and then were later destroyed by English soldiers in the sixteenth century. Although the automata were updated, rebuilt, renovated, and changed in the centuries after their installation, they remained functional and notable throughout that time. In the historiography of Hesdin and its automata, the innovator, Robert II, and the renovator, Philip the Good, Duke of Burgundy, who dramatically overhauled the entire park at Hesdin and added many new automata in the middle of the fifteenth century, are most often the central figures in the story. Yet today I would like to focus on another patron, Mahaut, and look more closely into her role in maintaining and adding to the automata and what this might say about her as a patron of art and technology.

First I want to give a brief bit of background on Hesdin and the installation of the original automata, as well as a brief bit of context about Mahaut's life. Robert began reconstruction of the castle and the creation of the park at Hesdin while he was serving as regent for the Angevin monarchy in Sicily from I285 to I292. He returned to Hesdin in I292, bringing with him an Italian knight, Renaud Coignet, whom he named guardian of his lands ["garde de notre terre"] and placed him in charge of the renovations of the castle and park. Coignet enlarged the park, repaired the walls around it, and began to oversee construction of the buildings in the park. Near an artificial lake there was a house, around which were several pavilions: the "Gloriette," a chapel made of glass, and the Gallery of Delights. Part of the gallery consisted of a bridge over the lake. The bridge was adorned with six groups of monkey marionettes. Additionally, there were mechanized fountains, a 
large sundial supported by lions and wild men, and a bellows-operated organ. Household accounts from I294-95 detail payment to laborers for their work on the park of Hesdin, including work on plumbing for the mechanized fountains. "Tailleurs de coutel," or metal smiths, were paid for work done to the bridge of the pavilion in the park, for a moving or mechanized boar's head on the wall of the pavilion, and for work done to the "ymaginetes." The mention of these "ymaginetes" strongly recalls the "ymages" (automata) in romance, chansons, historical chronicle, and epic, yet it is unclear what the "ymaginetes" actually were, as the word can refer to a moving or non-moving statue. In the records for 1300 , there is also a reference to clockwork, in the form of payment for a piece of iron for the clockworks ["un pieche de fer as orloges"]. It is not entirely clear what was meant by "orloges," given that mechanical clocks had not yet been invented. It could be a reference to an elaborate water clock with automata, or perhaps in conjunction with the sundial.

Robert II died in 1302, and Mahaut continued renovating the park and "engiens d'esbattements" at Hesdin until her death in I329. Mahaut was politically well connected, astute, and powerful. Through her father, Robert, she was part of the royal Capetian family; her father was the grandson of Louis VIII and Blanche of Castile. In her own lifetime, Mahaut was the niece of King Louis IX (St. Louis), cousin to kings Philip III and IV, and mother-in-law to kings Philip V and Charles IV. She married the Count of Burgundy (not to be confused with the duchy of Burgundy; the county of Burgundy corresponds to Franche-Comté) in $\mathrm{I}_{28}$, but became countess of Artois after her father died in 1302 . She was widowed the same year, and never remarried. Mahaut's inheritance was based on proximity of blood as Robert's son (and Mahaut's brother) Philip of Artois died in I298. However, in order to claim her inheritance, Mahaut had to repeatedly defend her claims to the county of Artois in court as her nephew, Philip's son Robert, challenged her claim. Eventually, her title was upheld, and she became one of the few women of her time to hold land and title suo jure rather than through her husband.

Hesdin was Mahaut's favorite residence in her county, and once she was countess she ensured that the existing "engiens" were maintained and also funded the construction of new features in the park. In 1304, for example, there was a bill for 300 nails "to recover the skins of the 
monkeys in the marsh." These monkeys were covered in badger skin and were rehabilitated every year or two until I343. By around I3IO, the mechanical works at Hesdin required someone to see to their maintenance, and Jacques de Boulogne, trained as a painter, was appointed "maistre des engiens du chastel et des peintres." He is part of a family of painters that appears regularly in the archival accounts for Hesdin beginning in the last years of the thirteenth century. However, by around I3IO, it appears that Jacques (who from this point onward is mentioned more than anyone else in his family) was occupied more with the engiens than with other work. In accordance with Mahaut's wishes, he received, between I3IO and I3I2, two sous tournois per day and a rent of ten pounds parisis per year for his work as overseer of the engines. In I3I4, the monkeys were recovered and horns were added, giving them the appearance of satyrs or demons. Unfortunately, there is no further mention of how these monkey-satyrs made their gestures; they may have been mechanical marionettes or powered by hidden human agency. However, given the elaborate fountains and mechanical birds also found at Hesdin, it seems more likely that they were operated by some kind of weight-driven mechanical device. The plumbing for the fountains was also regularly repaired, and in 1314 repairs were made to mechanical birds that spouted water. These birds were made from wood and gilded over with four hundredweight of gold. The moving birds were placed in the "Gloriette" and were joined the following year by a mechanically gesticulating king. The exact mechanism of the king is not described in detail; however, given its proximity to the hydraulic-powered birds, one may assume that the figure of the king may have also moved by waterpower, perhaps in conjunction with moving weights. For the rest of Mahaut's tenure as countess, the household accounts for Hesdin detail extensive spending on repainting, gilding, plastering, and repairing the fountains, water-jets, sundial, monkeys, and other figures in the park, as well as work done on "le cambre Madame" [Madame's chamber].

In the household accounts for Hesdin there is no smoking gun, no piece of evidence to suggest that the automata were built at Mahaut's design, and it is not entirely clear how her father was inspired to create a park with automata. Robert II, and his lieutenant, Coignet, may have gotten the idea for the park at Hesdin, filled with mechanized fountains 
and decorated with moving statues, as well as other automata, from late twelfth- and thirteenth century literature, which often depicted the pleasure gardens of oriental caliphs and emirs as well as the golden courtiers and musicians of history, legend, and romance. However, it is equally likely that Robert learned of these kinds of actual pleasure gardens, with elaborate fountains and automata, during the seven years he spent in Sicily. Furthermore, Coignet, Robert's agent and the overseer of the construction of the park and pavilion at Hesdin, was from Apulia, part of the Kingdom of Sicily, where Muslim and Christian literature, aesthetics, philosophy, and science had been enmeshed for over two hundred years. It is extremely likely that Robert and Renaud either saw or heard of gardens with water fountains, mechanical birds, and other automata from Muslim sources and perhaps met people who knew how to build them. Even the term "Gloriette," which one finds in the archival accounts of the park at Hesdin, was originally used to describe pleasure gardens in Muslim Spain. Furthermore, there was a chateau in Palermo, during the time of Robert's sojourn in Sicily, called “El Aziz," or, in French "Le Glorieux," and which was noted for its beautiful gardens.

Yet, despite the fact that the archival sources do not mention Mahaut directly, the works carried out on the automata at Hesdin during her time as countess, as well as her interest in fostering the decorative arts, her interest in preserving her father's legacy, and her ties to French crown, suggest that she took an active role in updating the automata at Hesdin. Archival evidence shows that while Mahaut was countess, she spent enormous sums of money on painting, sculpture, and construction at numerous chateaux in Artois, including Hesdin. At Hesdin, she continued work on the chapel, as well as work on the towers, doors, and interior rooms and continued to pay for regular work on the plumbing for the fountains and redecorating the sundial. She also commanded that a statue of a knight on horseback, made to resemble her father, be placed in the church of Notre-Dame de Boulogne, built specifically to honor her father. Furthermore, given Mahaut's ties of blood and marriage to French royalty, Hesdin was often a site of royal visits. For example, her younger daughter Blanche married Charles, a younger son of King Philip IV, at Hesdin in 1308 .

Even after Mahaut's death, Hesdin remained connected to the French 
crown. Her daughter, Jeanne, queen of France and wife of Philip V, inherited her mother's title in I329, but outlived her mother by only one year. Her eldest daughter, also named Jeanne (III), inherited the title of Countess of Artois in her own right, as well as holding the title of Duchess of Burgundy through her marriage to Eudes IV, Duke of Burgundy (it was at this moment that Artois became part of Burgundy). Like Jeanne III, Eudes was also part of the larger Capetian dynasty and was brotherin-law to the Valois king Philip VI. During Jeanne's and Eudes's lifetimes (they died in 1349 and I350, respectively), members of the French royal family continued to visit Hesdin and enjoy the automata there. Furthermore, beginning around 1320 , the French royal family began to collect elaborate table fountains and water clocks. While this collection ballooned under the Valois kings (from I328), one of the earliest extant examples of a musical table fountain, with multiple moving parts, now at the Cleveland Museum of Art, dates from the I320s. While it is certainly possible that the French court became enamored with this particular kind of automata from accounts of them in travelers' tales, romances, and histories, it is likely that the automata at Hesdin, expanded under the conservatorship of Mahaut and her heirs, provided them with material, as opposed to textual, examples of the ability of skilled artisans to create objects that, only a few decades prior, could be encountered only in texts or by travel to distant lands. Mahaut's interest in and support of her father's pleasure garden and her desire to expand and modify the automata played an important role in the diffusion of automata and the technology to create them in the fourteenth century. 